\title{
Co-movements Between Chinese and CBOT Grain Futures Markets: Some New Evidence Based on DCC-GARCH Model
}

\author{
Meng $\mathrm{Ou}$ \\ Institute of Quality Development \\ Kunming University of Science and Technology \\ Kunming, China
}

\author{
Jie Li* \\ Institute of Quality Development \\ Kunming University of Science and Technology \\ Kunming, China \\ 47723087@qq.com*
}

\begin{abstract}
Based on the bivariate DCC-GARCH model, this paper discusses the dynamic relationship between domestic and international grain futures market prices. The results show that domestic and foreign grain futures markets have a long-term integration trend and the dynamic correlation coefficient of soybean and wheat futures markets has significant time-varying characteristics, showing the phenomenon of wave aggregation; the grain futures market at home and abroad has strong linkage, among which soybean is the strongest, maize is the second, and wheat is the weakest.
\end{abstract}

Keywords-Grain futures market; Price linkage; DCC-GARCH

\section{INTRODUCTION}

Since 2001, with the accession to the World Trade Organization (WTO), the scale of China's grain imports has grown rapidly, and the internationalization degree of the grain market has also increased. In addition to the domestic supply and demand relations, the impact of international market on grain prices has begun to increase, and the linkage between domestic and international food prices has become very strong. However, in recent years, global food prices have fluctuated sharply, which has also affected the stability of domestic food prices. In the open economic environment, the major problem facing national grain security is to balance the interests and risks of the International Market. This requires a clear understanding of the fluctuation law of grain price at home and abroad.

The futures transmission mechanism of international grain prices is to affect futures and spot price movements of other markets by influencing commodity trading, and even to affect the pricing power of a country's grain market. With the development of the world futures market, the liquidity of capital has increased, and the linkage between various futures markets has been further strengthened. The futures market has become a bridge for the mutual transmission of food prices among most countries [1].

\section{LITERATURE REVIEW}

From the perspective of the futures transmission path, foreign scholars have studied the futures market very early. Alexander \& Wyeth (1994) used the Engel-Grange two-step method to test the Indonesian rice market and found a long- term integration between the domestic and international market prices [2]. Bettendorf \& Verboven (2000) by comparing several agricultural futures exchanges also believe that the Chicago Futures Exchange agricultural futures prices have a leading role in other futures market prices [3]. Ceballos et al. (2015) analyzed the price transmission mechanism for grain from international to domestic in 27 developing countries, using GARCH model, and found that the larger the scale of a country's trade imports and exports, the stronger the transmission effect of grain fluctuation [4].

Due to the slow development of China's futures market, academic research is relatively late. Zhao (2004) applied the relevant analysis and analysis of variance to explore the degree of integration and correlation between China's futures market and international futures market and found that Chinese futures market has a high correlation with the international futures market [5]. Liu (2017) pointed out in the study that grain import and export trade, futures market and currency exchange rates are the main transmission paths of food price fluctuation under open environment [6]. Wu et al. (2017), when studying the transmission effect of agricultural product financialization on corn price fluctuations, demonstrated that the futures market, international oil price and US dollar exchange rate are the most significant forces affecting food price volatility by constructing a price financialization driving system [7].

From the existing research, scholars have confirmed the significant influence of overseas market on China's inner market from the perspective of logical reasoning and empirical results, but in the selection of methods, they are more relaying on the static correlation analysis, based on linear regression model. The method lacks an examination of the dynamic correlation of time-varying variables. Therefore, based on the bivariate DCC-GARCH model, this paper discusses the dynamic relationship between domestic and international grain futures market prices, which supplements the previous research.

\section{METHODOLOGY}

The DCC-GARCH model proposed by Engle (2002) [8] improves the CCC-GARCH model, which is used to describing the constant conditional correlation, and can be applied to analyze the dynamic relationships of financial variables through calculating the coefficient of dynamic conditions. So 
we adopt this method to analyze the dynamic correlation of grain prices between Chinese and Chicago Board of Trade (CBOT) grain futures markets. Equation (1) is the conditional mean for vector of returns. The DCC-GARCH model is showed as (2), and inside (2) there are (3) (4) and (5).

$$
y_{t}=c+\varepsilon_{t}, \quad \varepsilon_{t} \mid \Omega_{t-1} \square N\left(0, H_{t}\right)
$$

$$
H_{t}=D_{t} R_{t} D_{t}
$$

$$
\begin{gathered}
R_{t}=\operatorname{diag}\left(q_{i i, t}^{-1 / 2}\right) Q_{t} \operatorname{diag}\left(q_{i i, t}^{-1 / 2}\right) \\
D_{t}=\operatorname{diag}\left(\sqrt{h_{i i, t}}\right) \\
Q_{t}=\left(q_{i, j, t}\right)=(1-a-\beta) \bar{Q}+ \\
a\left(\mu_{t-1} \mu_{t-1}^{\prime}\right)+\beta Q_{t-1}
\end{gathered}
$$

Where $h_{i, j, t}$ is a univariate GARCH process; $y_{t}$ is a sequence of exchange return, $c$ is the conditional mean vector, and $\varepsilon_{t}$ is a vector of forecast errors. $\mu_{i t}=\varepsilon_{i t} / \sqrt{h_{i i, t}}$ represents standardized residuals, $Q_{t}$ is a positive definite matrix; $\bar{Q}$ is the unconditional covariance matrix; The coefficients of the model is $\alpha$ and $\beta$, and they must be satisfying $\alpha>0, \beta>0$, and $\alpha+\beta<1 . \rho_{i, j, t}=q_{i, j, t} / \sqrt{q_{i, i, t} q_{j, j, t}}$ is the dynamic correlation coefficient of DCC-GARCH, which reflects the conditional correlation between the residuals. The larger the $\beta$ is, the greater the variation of the dynamic correlation coefficient is. The larger the $\alpha+\beta<1$ is, the stronger the relative dynamic correlation is.
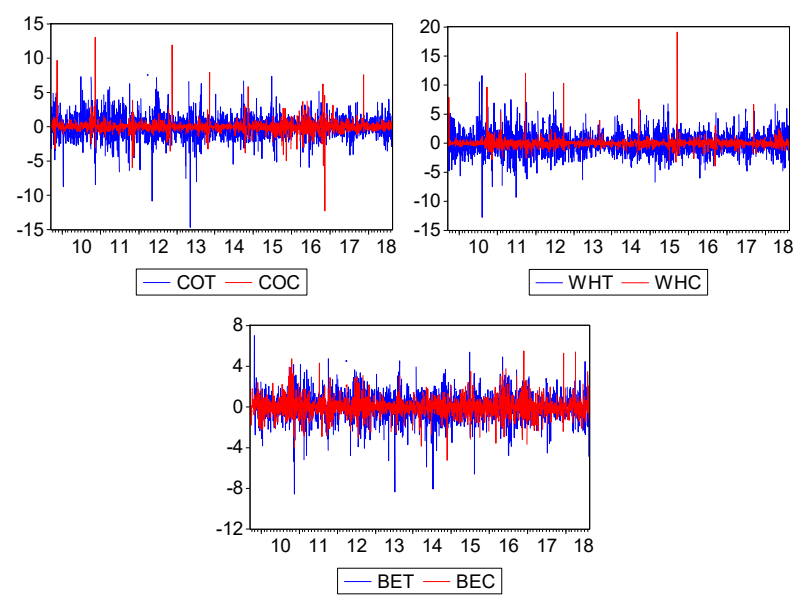

Fig. 1. Fluctuation chart of grain futures logarithmic yield.
The coefficient $\rho_{i, j, t}$ will be estimated in two steps. First, the univariate GARCH model of each market return rate is estimated, and the standard residual sequence is obtained by removing the residual with the obtained conditional variance. Second, the coefficient $\rho$ will be estimated through maximum likelihood estimate, basing on the conditional variances of standardized residuals.

\section{DATA}

We selected the CBOT $\sigma \circ \psi \beta \varepsilon \alpha v \sigma$, CBOT corn, and CBOT wheat in the Chicago futures market as research objects to represent the international futures market prices, which were expressed by BET, COT, and WHT, respectively. As to domestic futures market prices, we selected the No.2 Soybean and corn of Dalian Commodity Exchange and the wheat of Zhengzhou Commodity Exchange as research objects, which were represented by BEC, COC and WHC respectively. The data came from Wind, an online Real time Financial Information Terminal of China. The sample interval is between September 15, 2009 and August 15, 2018. Considering CBOT market and both Chinese commodity exchanges have different trading hours, we choose the closing price of domestic and international grain future market as the sample price and the samples were matched according to the actual common transaction date, and 2099 sets of observations were obtained except for holidays. At the same time, in order to exclude the different currencies and exchange rate effects of domestic and foreign transactions, the samples are all denominated in local currency and converted into daily logarithmic returns. Fig. 1 reveals the fluctuations in the rate of return on grain prices for the same species, and the related data description and test results are presented in Table I.

Referring to Table I, we can see that the volatility of grain futures prices in wheat and corn futures markets is quite different and the price volatility consistency of wheat markets is the worst. The consistency of grain futures prices in soybean futures markets is the strongest. In a short period of time, the domestic and international grain markets have obvious volatility cluster effects.

From the statistical analysis of Table I, the investment risk of foreign grain futures market is greater than domestic, for the mean price of domestic is larger and the standard deviation is low. The skewness coefficient and the kurtosis coefficient indicate that each variable sequence has a sharp and thick tail characteristic with asymmetric financial sequence distribution. The results of Jarque-Bera test show that the sequence of grain price returns is not suitable for normal distribution. The futures price return is a stable time series, which can be seen from ADF test results. $\mathrm{Q}(12)$, the result of $\mathrm{ARCH}-\mathrm{LM}$ test, is significantly different from zero, indicating that there is a wave clustering phenomenon in the order, which is consistent with the analysis of the results given in Fig. 1, and the Ljung-Box test shows the results are also significantly different from 0 . Therefore, it is suitable to use bivariate DCC-GARCH model to study the Co-movements of grain futures price between Chinese and CBOT grain futures markets. 
TABLE I.

STATISTICS DESCRIPTIVE AND TEST RESULTS

\begin{tabular}{|c|c|c|c|c|c|c|}
\hline & BET & COT & WHT & BEC & $\mathrm{COC}$ & WHC \\
\hline Mean & -0.0021 & -0.0021 & -0.0056 & 0.0027 & 0.0049 & 0.0084 \\
\hline Std. Dev. & 1.3400 & 1.7190 & 1.9143 & 0.8783 & 0.9205 & 0.8456 \\
\hline Skewness & -0.4302 & -0.3248 & 0.2482 & -0.3648 & 2.4364 & 9.4083 \\
\hline Kurtosis & 6.7080 & 8.5763 & 6.2100 & 8.1339 & 66.233 & 173.67 \\
\hline Jarque-Bera & $1266.63^{* * *}$ & $2755.1^{* * *}$ & $922.31^{* * *}$ & $2350.6^{* * *}$ & $351600^{* * *}$ & $2577^{* * *}$ \\
\hline $\mathrm{Q}(12)$ & $21.604^{* *}$ & $26.100^{* * *}$ & $29.478^{* * *}$ & $51.950^{* * *}$ & $22.425^{* *}$ & $26.888^{* * *}$ \\
\hline $\mathrm{ADF}$ & $-47.511^{* * *}$ & $-45.356^{* * *}$ & $-44.248^{* * *}$ & $-40.108^{* * *}$ & $-46.064^{* * *}$ & $-46.820^{* * *}$ \\
\hline
\end{tabular}

a. * Significant at $10 \%$ level, ${ }^{* *}$ Significant at $5 \%$ level, ${ }^{* * *}$ Significant at $1 \%$ level.

\section{Results}

Using DCC-GARCH model to analyze the price linkage of grain futures market at home and abroad, two steps are needed. In the first step, GARCH $(1,1)$ model of each return sequence is estimated and the conditional variance is obtained; in the second step, based on the established GARCH model and the calculated conditional variances standardized residuals, the parameters and correlation coefficients of dynamic conditions are estimated through maximum likelihood, showing in Table II and III.

TABLE II. RESULTS OF PARAMETER ESTIMATION OF DCC-GARCH MODEL

\begin{tabular}{|l|c|c|c|}
\hline \multicolumn{1}{|c|}{ coefficients } & BET-BEC & COT-COC & WHT-WHC \\
\hline \multirow{2}{*}{$\operatorname{DCC}(\alpha)$} & $\begin{array}{c}0.0051^{* *} \\
(2.3939)\end{array}$ & $\begin{array}{c}0.0032^{* * *} \\
(3.5949)\end{array}$ & $\begin{array}{l}0.0144^{* *} \\
(2.1614)\end{array}$ \\
\hline \multirow{2}{*}{$\operatorname{DCC}(\beta)$} & $0.9930^{* * *}$ & $0.9454^{* * *}$ & $0.9727^{* * *}$ \\
& $(295.50)$ & $(11.324)$ & $(72.239)$ \\
\hline $\operatorname{DCC}(\alpha+\beta)$ & 0.9980 & 0.9486 & 0.9871 \\
\hline
\end{tabular}

TABLE III. BASIC STATISTICS OF DYNAMIC CONDITIONAL COEFFICIENT

\begin{tabular}{|l|c|c|c|}
\hline \multicolumn{1}{|c|}{ coefficients } & BET-BEC & COT-COC & WHT-WHC \\
\hline Mean & 0.1609 & 0.0603 & 0.0303 \\
\hline Max & 0.3704 & 0.1494 & 0.2568 \\
\hline Min & 0.0120 & -0.1038 & -0.0932 \\
\hline Std. Dev. & 0.0798 & 0.0115 & 0.0629 \\
\hline
\end{tabular}

It can be seen from Table II that the parameters $\alpha \beta$ are significantly different from zero and $\alpha+\beta<1$, which indicates that the overall operation of the model is stable. The fitting effect is good through inspection. The coefficients $\alpha+\beta$ of the three grain futures are very close to 1 , indicating that there is a continuous linkage between domestic and foreign grain futures. In Table III, the dynamic correlation coefficient of soybean is significantly higher than the other two types of products, that is to say, the price linkage of soybean futures market at home and abroad is stronger, and the price trend is more similar, which is consistent with the results from Fig. 1, so there is a certain risk contagion between the mutual futures markets. This is related to the low production of soybeans in China and its overdependence on imports. In terms of wheat and corn, China is a major producer, and they are protected by national policies, so domestic and foreign markets both have a connection and a certain degree of separation. Therefore, reflected in the dynamic correlation coefficient is that the influence coefficient value is not high, and there will be positive and negative fluctuations.

In addition, Fig. 2 shows that the dynamic correlation coefficient of domestic and foreign soybean and wheat futures markets has significant time-varying throughout the cycle, while the linkage of corn futures is relatively stable. The linkage between domestic and foreign soybean futures markets is greater but not steady than that of wheat and corn markets, which reminds us to pay close attention to the change of foreign futures market price and prevent volatility spillover from affecting the grain price in China.

\section{SUMMARY}

In the context of China's open economy and market, this paper discusses the dynamic relationship between domestic and international grain futures market prices based on the bivariate DCC-GARCH model, and draws the following conclusions: domestic and foreign grain futures markets have a long-term integration trend and the dynamic correlation coefficient of soybean and wheat futures markets has significant timevarying characteristics, showing the phenomenon of wave aggregation; the grain futures market at home and abroad has strong linkage, among which soybean is the strongest, maize is the second, and wheat is the weakest.

It can be seen from the conclusion that domestic and CBOT grain futures markets have different degrees of linkage, which makes China's grain price inevitably vulnerable to the fluctuations of international grain futures price. The government should take note of the potential risks and take precautions in advance based on the dynamic relevance of the grain futures price. To ensure the food security, we should vigorously develop the futures market and strive for pricing power. Or we can moderately increase grain stock reserves, closely monitor foreign futures price changes, and prevent adverse effects of foreign risk spillovers on China's futures market. 
BET-BEC
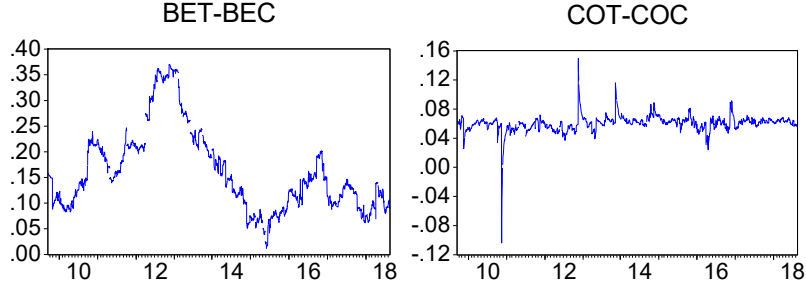

WHT-WHC

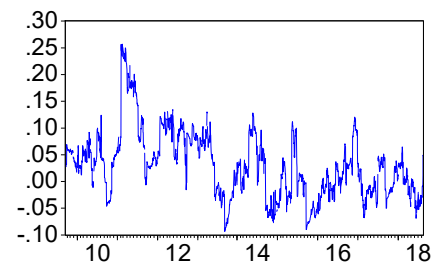

Fig. 2. Dynamic correlation coefficient of grain futures.

\section{REFERENCES}

[1] C.Y. Liu and R. Wang, "Study on transmission mechanism of international large amount of food price on China's food price based on soybean," Prices Monthly, vol. 8, pp. 7-11, 2015.

[2] C. Alexander and J. Wyeth, "Cointegration and market integration: An application to the Indonesian rice market," Journal of Development Studies, vol. 30, pp. 303-334, 1994.

[3] L. Bettendorf and F. Verboven, "Incomplete transmission of coffee bean prices: evidence from the Netherlands," European Review of Agricultural Economics, vol. 27, pp. 1-16, 2000.

[4] F. Ceballos, M.A. Hernandez, N. Minot, and M. Robles, "Grain Price and Volatility Transmission from International to Domestic Markets in Developing Countries," World Development, vol. 94, pp. 305-320, 2015.

[5] J.W. Zhao, "Analysis of the association between Chinese and international commodity futures markets and associated co-integration tests," China Soft Science, vol. 5, pp. 34-40, 2004.

[6] Y.P. Liu, "An analysis of transmission mechanism of grain price fluctuation under opening environment and its countermeasures," Prices Monthly, vol. 10, pp. 37-39, 2017.

[7] H.X. Wu, Y. Ge, H.T. Shi, and S.R. Han, "The transmission effect of agricultural financilization on corn prices," Journal of Xiamen University, vol. 2, pp. 138-148, 2017.

[8] R. Engle, "Dynamic conditional correlation-A simple class of multivariate GARCH models," Ssrn Electronic Journa, vol. 20, pp. 339$350,2002$. 